\title{
Line transect estimates of Irrawaddy dolphin abundance along the eastern Gulf Coast of Thailand
}

\author{
Ellen M. Hines ${ }^{1 *}$, Samantha Strindberg ${ }^{2}$, Chalatip Junchumpoo ${ }^{3}$, \\ Louisa S. Ponnampalam ${ }^{4,5}$, Anoukchika D. llangakoon ${ }^{6}$, Justine Jackson-Ricketts ${ }^{7}$ and \\ Somchai Monanunsap ${ }^{8}$ \\ ${ }^{1}$ Department of Geography and Environment, Romberg Tiburon Center for Environmental Studies, San Francisco State \\ University, Tiburon, CA, USA, ${ }^{2}$ Wildlife Conservation Society, Bronx, NY, USA, ${ }^{3}$ Department of Marine and Coastal \\ Resources, Eastern Marine and Coastal Resources Research Center, Rayong, Thailand, ${ }^{4}$ Institute of Ocean and Earth \\ Sciences, University of Malaya, Kuala Lumpur, Malaysia, ${ }^{5}$ The MareCet Research Organization, Kuala Lumpur, Malaysia, \\ ${ }^{6}$ Independent Researcher, Maharagama, Sri Lanka, ${ }^{7}$ Department of Ecology and Evolutionary Biology, University of \\ California, Santa Cruz, Santa Cruz, CA, USA, ${ }^{8}$ Department of Marine and Coastal Resources, Southern Marine and Coastal \\ Resources Research Center, Songkhla, Thailand
}

\section{OPEN ACCESS}

Edited by:

Romuald Lipcius,

College of William \& Mary, USA

Reviewed by:

Laura J. May-Collado,

University of Vermont, USA

Christine Nicole Meynard,

College of William \& Mary, USA

*Correspondence: Ellen M. Hines,

Department of Geography and Environment, Romberg Tiburon Center for Environmental Studies, San

Francisco State University, 3150 Paradise Dr., Tiburon, CA 94920, USA ehines@sfsu.edu

Specialty section:

This article was submitted to Marine Conservation and Sustainability, a section of the journal Frontiers in Marine Science

Received: 24 May 2015 Accepted: 20 August 2015 Published: 03 September 2015

Citation:

Hines EM, Strindberg S, Junchumpoo C, Ponnampalam LS, llangakoon AD, Jackson-Ricketts $J$ and Monanunsap S (2015) Line transect estimates of Irrawaddy dolphin abundance along the eastern Gulf Coast of Thailand.

Front. Mar. Sci. 2:63.

doi: 10.3389/fmars.2015.00063
Effective conservation of coastal marine mammals is largely dependent on reliable knowledge of their abundance, as well as the ecological and human factors driving their distribution. In developing countries, lack of resources and capacity frequently impedes research needed to estimate abundance and to determine the ecological requirements of coastal marine mammals and the impact of threats related to coastal development and fisheries. Over the course of 5 years, we developed practical research methods and trained local scientists in Thailand to use accepted line transect distance sampling methods for abundance assessment. The study focused on a little-known coastal and freshwater species found throughout Southeast Asia, namely the Irrawaddy dolphin, which has been sighted regularly along the coast of the eastern Gulf of Thailand. During 5 years of line transect boat surveys in Trat Province, the eastern-most province in Thailand, we found an average of 423 dolphins distributed within $12 \mathrm{~km}$ of the coast. Compared to other abundance estimates of coastal Irrawaddy dolphins in Southeast Asia, this is a relatively large number. This population could extend into the northern coast of Cambodia, where surveys are currently being planned. The Thai government has begun talks with Cambodia about a transboundary marine protected area that would include areas in both countries where coastal Irrawaddy dolphins are found. Collaboration between scientists in Thailand, Cambodia and Vietnam is further needed to determine dolphin movement and habitat use across borders.

Keywords: Irrawaddy dolphins, Orcaella brevirostris, eastern Gulf of Thailand, distance sampling, coastal dolphin abundance, line transects, small boat surveys

\section{Introduction}

As coastal areas are increasingly impacted by human population growth and development, gaps in knowledge about the abundance and habitat extents of coastal marine mammals obstruct effective management and conservation (Dawson et al., 2008; Dick and Hines, 2011). In many developing coastal regions, the extent and severity of threats (i.e., bycatch, pollution, overfishing) is largely 
unknown, and cannot be quantitatively evaluated without high quality abundance data (Dawson et al., 2008). Repeatable and practical methods have been outlined (Dawson et al., 2008) and tested (see for example Kreb, 2004; Hines et al., 2005; Dick and Hines, 2011; Minton et al., 2013) in remote areas and developing countries for line transect distance sampling surveys (Buckland et al., 2001). As part of a long-term research project to assess marine mammal abundance, distribution and threats along the eastern Gulf coast of Thailand, primarily in Trat Province, we found a relatively large population of Irrawaddy dolphins (Orcaella brevirostris) and have had repeated sightings of two other species:Indo-Pacific humpback dolphins (Sousa chinensis) and Indo-Pacific finless porpoises (Neophocaena phocaenoides). None of these species had been studied in this area previous to our project's commencement in 2008 . However, the numbers of sightings of humpback dolphins and finless porpoises were not large enough to permit a distance sampling analysis. In this paper we report on the results of our line transect surveys for Irrawaddy dolphins for 5 years: 2008, 2009, 2012, 2013, and 2014.

Irrawaddy dolphins can be found in riverine, estuarine and coastal waters throughout the tropical and subtropical IndoPacific region (Stacey and Arnold, 1999; Minton et al., 2013). Throughout Southeast Asia, the Irrawaddy dolphin is generally found in shallow estuaries and coastal waters (Reeves et al., 2008). For example, in the Philippines, most sightings were made at a depth of $<6 \mathrm{~m}$ (Dolar et al., 2002). Largely because they are distributed close to coastal areas, Irrawaddy dolphins are exposed to coastal development and fishing activities likely to result in them becoming incidental bycatch (Dolar et al., 2002; Reeves et al., 2003). Little is known about nearshore Irrawaddy dolphins in the Gulf of Thailand. Chantrapornsyl et al. (1996), Stacey and Leatherwood (1997); Stacey and Arnold (1999), and Anderson and Kinze (1999) note that while records of occurrence are few, Irrawaddy dolphins have been reported along the coast of the Gulf of Thailand, with an early report of a skull found in Khlong Yai, in Trat province, in 1914 (Anderson and Kinze, 1999). The International Union for the Conservation of Nature (IUCN) classes the Irrawaddy dolphin as a vulnerable species with a decreasing trend on its Red List of Threatened Species (Reeves et al., 2008). In Thailand, the Irrawaddy dolphin is included under the 1992 Wild Animals Preservation and Protection Act. In the IUCN/SSC Cetacean Specialist Groups' 2002-2010 Conservation Action Plan for the World's Cetaceans, one of the recommended research initiatives concerning the status of coastal cetaceans in Thailand addresses a need to identify areas of "cetacean abundance for special conservation attention," as well as to document fishing intensity in these areas (Reeves et al., 2003, p. 60). These dolphins are a species of concern in Thailand, as evidenced by Thailand's sponsorship of Irrawaddy dolphins for CITES Appendix I protection in Bangkok at the Conference of the Parties in 2004 (CITES, 2004).

Within Thailand, Irrawaddy dolphins are distributed in Phang Nga and Krabi Bays as well as Satun Province along the Andaman Sea coast, Songkhla Lake, and several locations around the Gulf of Thailand (Bonhote, 1904; Pilleri and Gihr,
1974; Chantrapornsyl et al., 1996; Stacey, 1996; Adulyanukosol, 1999; Anderson and Kinze, 1999; Chantrapornsyl et al., 1999; Beasley et al., 2002; Smith et al., 2003; Perrin et al., 2005; Kittiwattanawong et al., 2007; Reeves et al., 2008) (Figure 1). The species has additionally been reported to occur within the Chao Phraya and Bang Prakong rivers (Adulyanukosol, 1999). Little is known about Irrawaddy dolphins along the Andaman Sea coast of Thailand. Occurrence records for Phang Nga and Krabi Bays are limited to fishermen's reports (Chantrapornsyl et al., 1996), while this species has been sighted off the Satun coast around Tarutao Island (Adulyanukosol, 1999; Perrin et al., 2005). The subpopulation in Songkhla Lake is considered Critically Endangered by the IUCN (Reeves et al., 2008). It is currently thought that Irrawaddy dolphins in the Lake number fewer than 30 individuals (Jutapruet, 2013), and are threatened by direct capture for Oceanaria, entanglement in fishing gear, habitat degradation, pollution, prey depletion due to overfishing, and inbreeding depression due to small population size and demographic isolation (Stacey, 1996; Beasley et al., 2002; Perrin et al., 2005; Kittiwattanawong et al., 2007; Reeves et al., 2008; Jutapruet, 2013).

Irrawaddy dolphins occur in many locations along the coast surrounding the Gulf of Thailand, from Surat Thani and Pattani Provinces on the western Gulf coast, through Samut Songkhram, Samut Sakhon, and Samut Prakan Provinces in the northern Gulf, to Chonburi, Rayong, Chanthaburi, and Trat Provinces on the eastern Gulf coast (Chantrapornsyl et al., 1996, 1999; Adulyanukosol, 1999; Anderson and Kinze, 1999). Generally, threats to Irrawaddy dolphins around the Gulf of Thailand include entanglement in fishing gear; habitat degradation due to coastal zone development, tourism, agriculture, aquaculture, and manufacturing; pollution from waste runoff; and live capture for Oceanaria (Perrin et al., 2005). In August of 1994, two Irrawaddy dolphins were found stranded in Surat Thani Province and one more stranded between 1996 and 1999 (Chantrapornsyl et al., 1996; Adulyanukosol, 1999). One stranding was recorded in Samut Songkhram Province (Adulyanukosol, 1999). In Trat Province, where this research took place, bycatch seems to be the most critical threat to Irrawaddy dolphins. Between 2010 and 2012, fishermen reported accidentally catching and killing 21 Irrawaddy dolphins, 10 of which were entangled in gillnets (Whitty, 2014). Over a period of 14 days in January and February 2013, 14 Irrawaddy dolphins and 3 finless porpoises were discovered stranded or dead in illegal fishing gear along the Trat coast. Necropsies confirmed that 10 of the animals were incidentally entangled in illegal fishing gear, although one of the finless porpoises had died due to parasites. For six, the cause of death was not determined due to decomposition (Junchompoo et al., 2014).

The goal of this research was to assess the conservation status of coastal cetaceans in Trat province. Information about the abundance of these dolphins is necessary to gauge the effects of bycatch, habitat degradation and other threats on the sustainability of this population. This assessment is urgently needed to contribute effectively to local/regional conservation and possible protected area management schemes, especially in a rapidly developing area. 


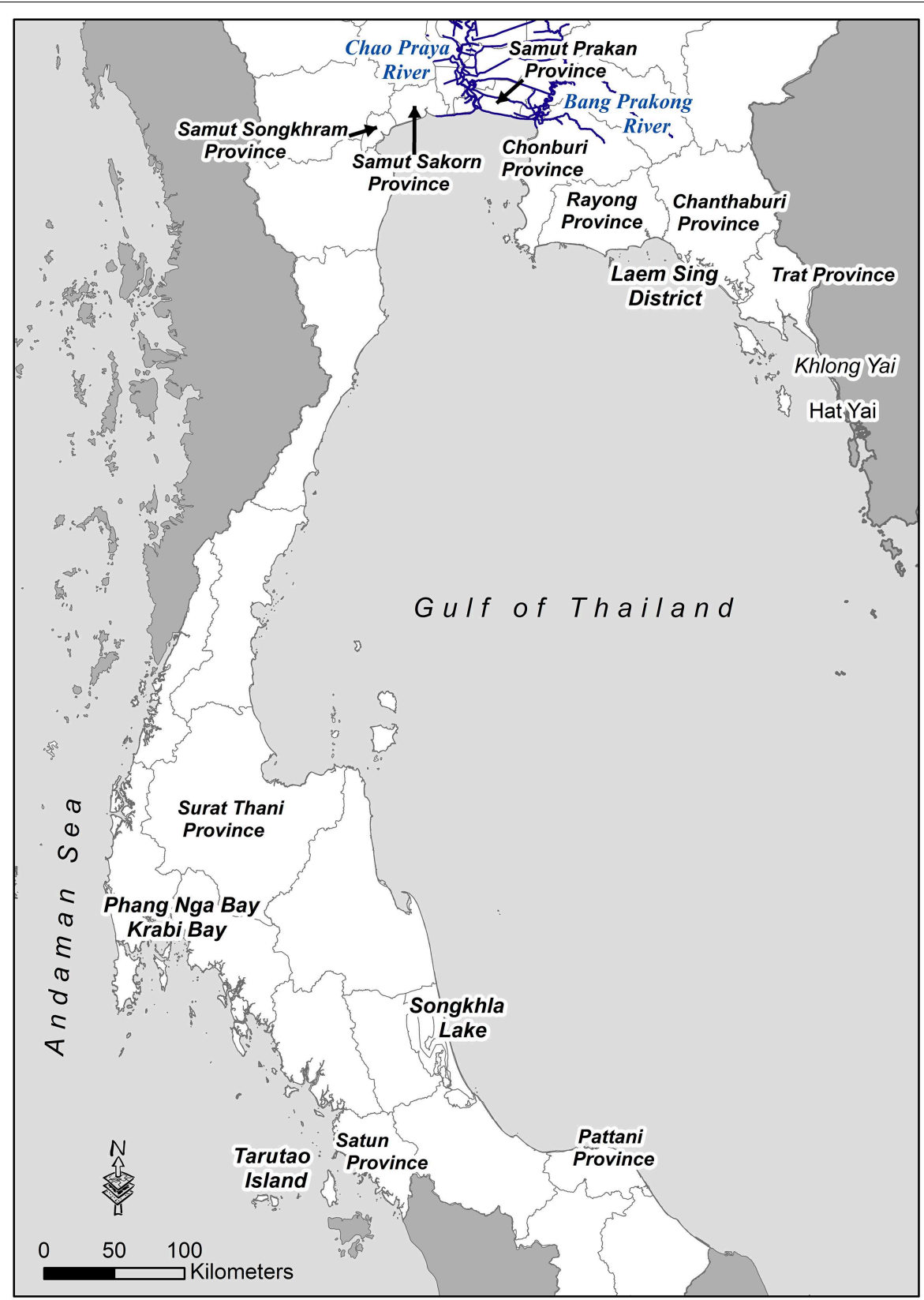

FIGURE 1 | Map of Thailand with Irrawaddy dolphin sighting areas mentioned in the text.

\section{Materials and Methods}

Trat Province is at the eastern boundary of Thailand, approximately $315 \mathrm{~km}$ east of Bangkok, extending to the Cambodian border (Figure 1). The northern coast of the Province is adjacent to an archipelago of islands. The northernmost island, Ko Chang, is a popular tourist area. Further east, into our field site, is Trat Bay, a wide, shallow bay with two large rivers emptying into it. The eastern extent of the Province is a narrow strip, at one point $1.5 \mathrm{~km}$ wide and $45 \mathrm{~km}$ long, with the steep Cardamom Mountains in Cambodia forming a natural border. Besides the city of Trat, above Trat Bay, Khlong Yai, a major fishing port, and Hat Yai, at the Cambodian border, the coast is relatively sparsely populated with fishing villages. The climate is tropical, with a dry season between November and March, and a wet southwest monsoon from April through November. According to tidal charts from the Royal Thai Navy, the tidal range is at maximum $3.0 \mathrm{~m}$.

For analysis of patterns of distribution and habitat use in further research, we divided our survey area into three strata, based on variations of geography and human use. The north stratum was in eastern Trat Bay, the middle, further down the 
strip, near the entrances of several rivers into coastal waters, and the south stratum near the fishing port of Khlong Yai toward the Cambodian border. During the surveys, our boat moved along zig-zag transect lines in each of the three survey strata: north, middle, and south (see Figure 2).

Distance sampling surveys along line transects are widely used to estimate density and abundance of cetacean populations (Buckland et al., 2001). We used Distance software (Thomas et al., 2010) and a geographic information system to design a line transect survey design for Irrawaddy dolphins in a stratified study area in the eastern Gulf coast of Thailand during five field seasons in 2008, 2009, 2012, 2013, and 2014. Our zig-zag survey design for boat-based transects is based on Strindberg and Buckland (2004). The design ensured reasonably even sampling probabilities across the study area (even sampling probabilities are an assumption underlying a standard distance sampling analysis), while maximizing on-effort time, or time spent following the transect looking for animals. Field groundtruthing of each line was conducted to account or adjust for shallow or impassable areas and to ensure the transect lines could be run in perpetuity with minimal difficulty. Our goal was to design a practical and repeatable systematic survey for this area that would allow for quantitative analysis of abundance and long-term monitoring of the dolphins in this area.

Surveys were conducted in January or February of each year, during the north-east monsoon, which has a lower change of rainfall in the eastern Gulf. Each year, the number of transect days varied, according to weather. Transects were completed in all strata in the survey area either two $(2012,2013,2014)$ or three times $(2008,2009)$ in a field season. All surveys were run from a 12-m fishing boat equipped with inboard engines, boat speed was kept at $10 \mathrm{kmh}^{-1}$. A team of three observers continuously scanned from the bow to $90^{\circ}$ Port and Starboard with the naked eye and $7 \times 50$ binoculars while on effort. For each dolphin group sighting detected during on-effort searching, waypoints were recorded into a handheld GPS unit at the sighting location, then three variables necessary to estimate density and abundance were immediately recorded: the estimated radial distance from the survey boat $(r)$ using binoculars with reticles, the angle $(\theta)$ between the transect line and the line of the detection using angle boards, and the number of animals seen. Once the initial data were recorded, the boat deviated from the transect to approach the dolphin group off effort, to within $10 \mathrm{~m}$ to record their location using the GPS unit. We also collected data on the species and number of animals in the group, general age composition (adult or calf), photographs for photo-identification when possible, behavioral data and environmental parameters. Afterwards, we returned to the location where the sighting was made and resumed transect effort. Environmental parameters were collected for each sighting, as well as every $30 \mathrm{~min}$ while on transect.

Density of Irrawaddy dolphin groups within the area surveyed is estimated as $\hat{D}_{s}=\frac{n \hat{f}(0)}{2 L}$, where $L$ denotes the aggregate length of the transects, $n$ is the number of groups observed, $f(0)$ is the probability density function of observed perpendicular distances evaluated at zero distance from the line. The density of groups $\hat{D}_{s}$ is multiplied by the estimated expected group size $\hat{E}(s)$ to obtain density of individuals $\hat{D}$, and this estimate is multiplied by the surface area of each survey stratum to obtain the corresponding abundance estimate of dolphins by stratum $(\hat{N})$. Overall density for the study area per year was obtained by calculating a mean of stratum estimates weighted by stratum area.

The Distance 6 software (Thomas et al., 2010) was used to analyze the data. The on-effort observations of Irrawaddy dolphin groups made from the line transects (Figure 2) were used for the distance sampling analysis. A stratified (by stratum or year) or pooled data approach was considered in fitting the detection function. Various combinations of key functions and adjustment term were considered to model the detection function (e.g., uniform + cosine or simple polynomial, half-normal + cosine or simple polynomial, hazard rate + cosine, or hermite polynomial). Goodness of fit tests were used to identify violations of assumptions. Exploratory analyses were conducted to examine options for truncation and grouping intervals to improve model fit for the detection function. Akaike's Information Criterion adjusted for small sample size (AICc) was used in final model selection. Encounter rate was estimated within each of the survey strata per year and its variance was estimated empirically using the replicate transect lines as samples. There may be a tendency for smaller dolphin groups to be missed more often than larger groups at large distances from the transect line, which can lead to "size bias" if the average group size is simply used during the estimation process. To test for bias in the estimate of group size, we applied a statistical hypothesis test at the 15\% $\alpha$-level to the regression of natural logarithm of group size against the probability of detection at distance $x$ from the line within the Distance software. If the regression was statistically significant the expected group size $[E(s)]$ was used, otherwise average group size was used to estimate density and abundance. Group size estimation was also stratified by survey stratum and year. Individual Irrawaddy dolphin density per stratum for each year and between sequential years was tested for statistically significant difference at the $5 \%$ significance level using a twosided $t$-test (Buckland et al., 2004). This $t$-test explicitly accounts for the lack of independence in the data that went into the densities being compared due to using a common detection function across strata and years.

\section{Results}

Table 1 summarizes the numbers of sightings and species for each year. We had between 45 and 83 on effort sightings of dolphins each year, which included between 151 and 341 animals. The geographic distribution of sightings for each year distributed across the strata are in Figure 2A (2008 and 2009), Figure 2B (2012 and 2013) and Figure 2C (2014). Even with all years combined, we did not have enough sightings of Indo-Pacific humpback dolphins or Indo-Pacific finless porpoises to fit a detection function to obtain an accurate abundance estimate. The encounter rate for Indo-Pacific humpback dolphins, for example, was 0.06 sightings $/ \mathrm{km}^{-1}$ of effort. 

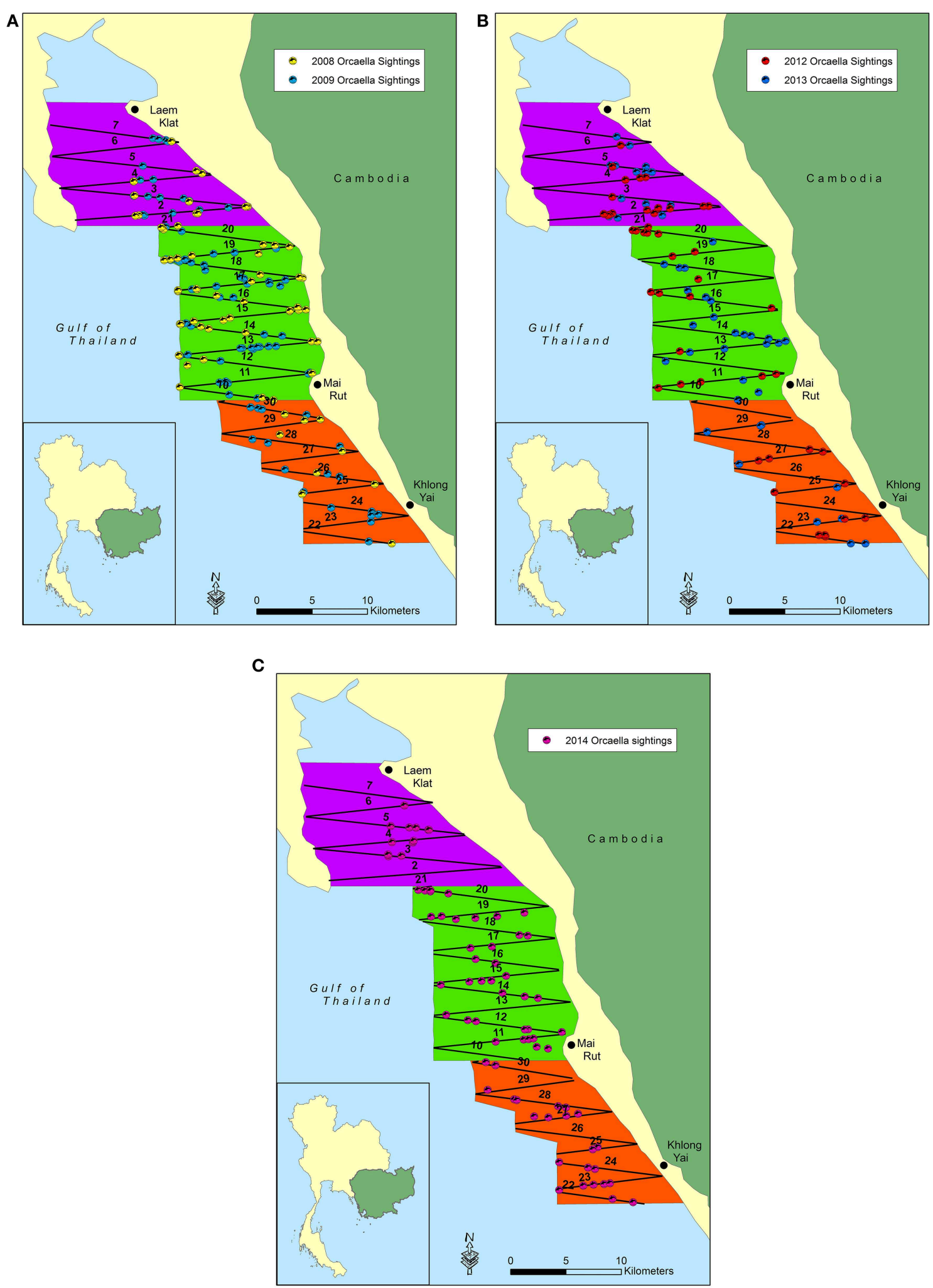

FIGURE 2 | (A) All on-effort sightings of Orcaella brevirostris in 2008 and 2009 surveys along the coast of Trat Province, on the eastern Gulf coast of Thailand. The purple area is the north strata closer to the shallow Bay. The green area is the shallow middle strata near several river mouths. The orange area is the south strata, a deeper area closer to the major fishing port of Khlong Yai. (B) All on-effort sightings of Orcaella brevirostris in 2012 and 2013 surveys along the coast of Trat Province, on the eastern Gulf coast of Thailand. (C) All on-effort sightings of Orcaella brevirostris in 2014 surveys along the coast of Trat Province, on the eastern Gulf coast of Thailand. 
The total effort per stratum and year for Irrawaddy dolphins are detailed in Table 2. In the final models, data were pooled across survey strata and years and grouped into five equalspaced intervals with right truncation at $450 \mathrm{~m}$ (10\% of the data). Pooling provided a more robust detection function (see Figure 3) due to some sample size issues when stratifying per year or survey stratum, and also due to issues with the data measurements. In the early years there was a heaping of angle estimates at zero which indicates that particularly small angle sizes were not being measured accurately. In the later years it seemed that observers may have been overcompensating as there were more observations than expected some distance from the line (with no movement of dolphins away from the observers before measurements were taken).

The final model was a half-normal with cosine adjustment terms, which gave a detection probability of about $38 \%$ and an effective half strip width of $171.26 \mathrm{~m}$ (see Figure 3). Estimates of encounter rate and expected group size for the Irrawaddy dolphins and survey stratum are also detailed in Table 2. Based

TABLE 1 | Sightings and numbers of Irrawaddy dolphins seen in $\mathbf{5}$ years of surveys along the eastern Gulf coast of Thailand.

\begin{tabular}{llcc}
\hline Year & Species & $\begin{array}{c}\text { No. of on-effort } \\
\text { sightings }\end{array}$ & $\begin{array}{c}\text { Numbers of } \\
\text { animals seen }\end{array}$ \\
\hline 2008 & Orcaella brevirostris & 62 & 248 \\
2009 & Orcaella brevirostris & 83 & 341 \\
2012 & Orcaella brevirostris & 52 & 266 \\
2013 & Orcaella brevirostris & 45 & 161 \\
2014 & Orcaella brevirostris & 67 & 151
\end{tabular}

on the $t$-test $p$-value being smaller than the specified significance level of $15 \%$, there is some indication of "size bias" in the North $(p=0.113)$ and Middle $(p=0.124)$ strata in 2009 and in the South $(p=0.125)$ in 2012, so the expected group size was used in those cases and the average group size for the remainder of the stratum-year combinations. The final estimates of Irrawaddy dolphin group and individual density, and abundance for each survey stratum per year and overall per year is shown in Table 3. Although there were differences between the strata per year and overall by sequential survey years, given the fairly high variance associated with the estimates, individual Irrawaddy dolphin densities overall were only significantly lower in 2012 compared to 2009. Only when considering one-tailed $t$-test results was the South stratum significantly lower than the Middle stratum in 2009, and the South stratum was also significantly lower than the North stratum in 2013.

\section{Discussion}

The average relative abundance estimate of 423 Irrawaddy dolphins within $12 \mathrm{~km}$ of the coast reflects the estimate of animals in our survey area based on the number of sightings averaged over the 5 years (Table 3). Averaged over these years, based on our sighting patterns, the top and middle strata had slightly more sightings and groups of animals, and the bottom strata the least, with the exception of 2012 (Table 3). During this year there was increased fishing activity near the port of Khlong Yai. Now that we have an abundance estimate, the next step is to continue to monitor the population for trends; to see whether the numbers increase or decrease or remain the same over the next 5 years.

TABLE 2 | Details of the total effort (L) per year in each survey stratum.

\begin{tabular}{|c|c|c|c|c|c|c|c|}
\hline Year & Stratum & $L(\mathrm{~km})$ & $n$ & $n / L\left(\mathrm{~km}^{-1}\right)$ & $95 \% \mathrm{Cl}$ & $E(\hat{\mathbf{S}})$ & $95 \% \mathrm{Cl}$ \\
\hline \multirow[t]{3}{*}{2008} & North & 125.89 & 10 & 0.079 & $(0.042-0.151)$ & 3.7 & (2.19-6.25) \\
\hline & Middle & 363.77 & 36 & 0.099 & $(0.057-0.171)$ & 3.53 & $(2.91-4.27)$ \\
\hline & South & 240.36 & 11 & 0.046 & $(0.022-0.096)$ & 4.64 & $(3.01-7.14)$ \\
\hline 2009 & North & 125.89 & 17 & 0.135 & $(0.079-0.230)$ & 3.10 & $(2.09-4.61)$ \\
\hline \multirow[t]{3}{*}{2012} & North & 125.88 & 20 & 0.159 & $(0.061-0.415)$ & 2.90 & $(2.00-4.20)$ \\
\hline & Middle & 241.14 & 13 & 0.054 & $(0.021-0.138)$ & 2.85 & $(2.07-3.92)$ \\
\hline & South & 160.24 & 10 & 0.062 & $(0.037-0.106)$ & 5.67 & (2.16-14.89) \\
\hline 2013 & North & 83.92 & 12 & 0.143 & (0.061-0.333) & 3.67 & $(2.40-5.60)$ \\
\hline \multirow{2}{*}{2014} & Middle & 241.14 & 31 & 0.129 & $(0.093-0.179)$ & 2.74 & $(1.90-3.96)$ \\
\hline & South & 160.24 & 22 & 0.137 & $(0.089-0.212)$ & 2.32 & (1.83-2.94) \\
\hline
\end{tabular}

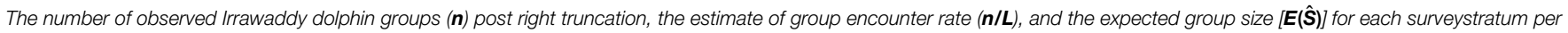
year with the corresponding $95 \%$ confidence intervals (95\% Cl). 


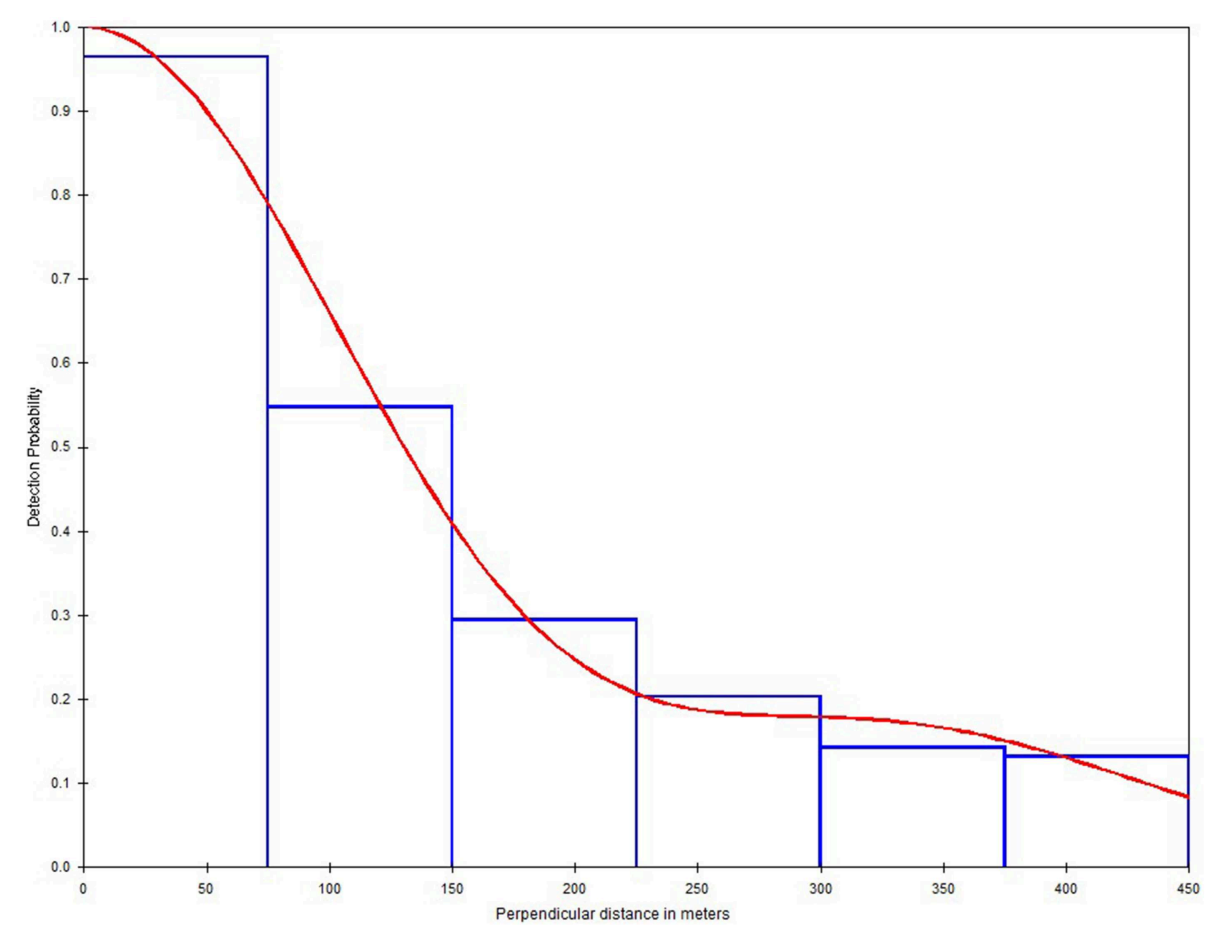

FIGURE 3 | Detection functions fitted to the perpendicular distances of observations of groups of Irrawaddy dolphins. On-effort sightings were pooled across survey strata and survey years. Data were grouped for final analysis using six equal-spaced intervals with right truncation at $450 \mathrm{~m}$.

Setting up the field methods and obtaining these estimates is a first step-knowing the population trends will provide us with a clearer idea of what the long-term prospects are for this species and whether conservation activities are effective.

Compared to other transect-based abundance estimates of coastal Irrawaddy dolphins in Southeast Asia, our present estimate is relatively large. A comparable project in the region is a 2 year line transect survey with similar methods for Irrawaddy dolphins, conducted in Sarawak, Malaysia in 2010 and 2011. The population estimate for this area was 129 dolphins, but included a river which contributed most of the sightings. The density of animals in coastal areas averaged 0.279 per $\mathrm{km}^{2}$, in contrast to our average density of 0.982 per $\mathrm{km}^{2}$ (Minton et al., 2013). Smith et al. (2004) surveyed a geographically isolated group of Irrawaddy's in the Philippines in 2001 and estimated an overall abundance of 77 animals. Research on coastal Irrawaddy's in the region is irregular and fragmented. Dolar and her collaborators have been investigating Irrawaddy dolphins in the Philippines and have recently discovered their presence in previously undocumented locations (Hines et al., in press). Kuit et al. (2014) are researching coastal dolphins in the Matang estuary of western Malaysia, but have not published abundance statistics. Kreb and Lim (2009) have estimated between 68 and 79 Irrawaddy dolphins are in Balikpapan Bay, in eastern Kalimantan, Indonesia. For a complete report on Irrawaddy dolphin presence and research throughout Southeast Asia, see Hines et al. (in press).

Despite having once been considered a common area of Irrawaddy dolphin occurrence (Stacey, 1996), few dolphins were seen in the islands west of the Trat coast and no dolphins were observed during a January 2014 survey in Chanthaburi and Rayong Provinces (Hines et al., 2013, 2014) (Figure 1). Modeling is underway to ascertain variations in environmental covariates and human use to help explain this marked difference in sightings. For now, the presence of so many dolphins is an indication that the Trat coast contains critical habitat for coastal Irrawaddy dolphins. We are working with the Thai Department of Marine and Coastal Resources (DMCR) on a long-term project to plan protective management areas.

We still need more data from nearby coastlines to determine the range of this population group. In Thailand, sightings of between 20 and 25 individuals were found by Tongnunui et al. (2011) in the Bang Pakong Estuary, approximately $250 \mathrm{~km}$ north of our fieldsite. We would recommend stable isotope analysis and photo-identification research to see if these animals mix with the dolphins we have seen in Trat. The Trat dolphins could also travel into the northern coast of Cambodia. In 2004, while on aerial surveys along the Cambodian coast, Hines et al. (2004) saw Irrawaddy dolphins on the northwestern coast near the Thai border. They had 24 sightings of approximately 79 dolphins, with a maximum group size of 15 . There have been reports of Irrawaddy dolphins in southwestern Vietnam, close to the Cambodian border ( $\mathrm{Vu}$ pers.comm). Coordination of efforts, particularly photo-identification, between scientists in Thailand, Cambodia and Vietnam is further needed to determine dolphin movement and habitat use across borders. 
TABLE 3 | Estimates of density (D) in number $/ \mathrm{km}^{2}$ (group density $\hat{D}_{s}$ in parentheses) and abundance $(\hat{\mathcal{N}})$ of Irrawaddy dolphins for each survey stratum per year and overall per year with their corresponding $95 \%$ confidence intervals $(95 \% \mathrm{Cl})$, and the percent coefficient of variation (\% $\mathrm{CV})$.

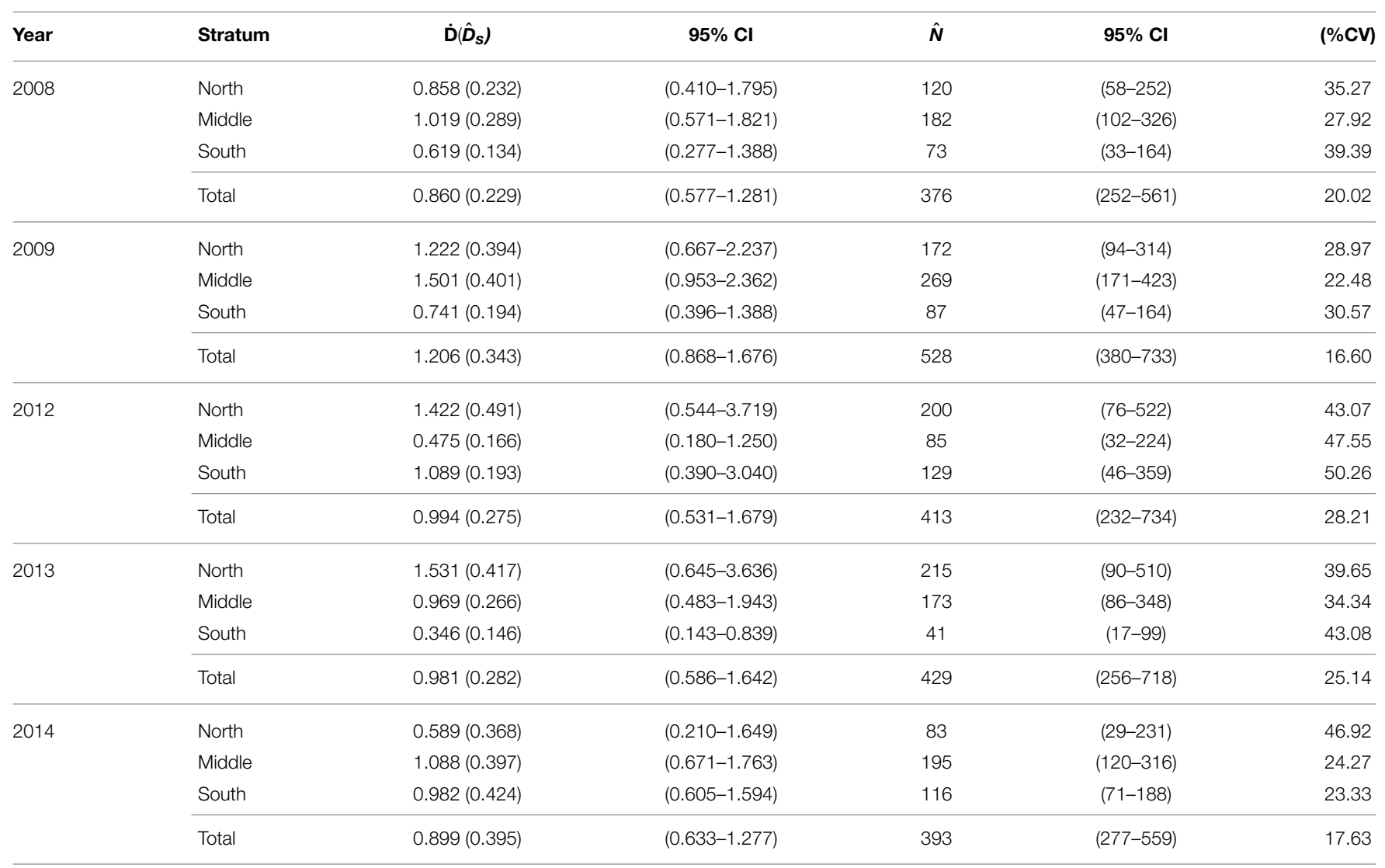

Over 5 years of research we were successful in creating a practical and repeatable systematic survey that allows for quantitative statistical analysis and long-term monitoring of the Irrawaddy dolphin population. Enough Irrawaddy dolphins were seen in the combined years for robust statistical analysis, with fewer issues in the sample data in later years, which shows the increasing skills of the international and Thai scientists trained in these methods. Also critical, each year the visibility of the scientists and our research increased conservation awareness in local villages. We stayed in local hotels run by villagers for all 5 years, hired a driver who is an active community member and conducted our research on a local fishing boat. We have given presentations and lectures at elementary schools in Trat Province, attended village council meetings and explained our research and concerns about cetacean bycatch and plastic pollution. Local teachers and students came on our boats and assisted with our fieldwork, and we worked with a local conservation group to take samples and teach about incidental bycatch in a local village after bycaught animals were found both on several beaches and floating in the water during our surveys.

This is a critical first step, however we still have important questions: What are population trends in this group of animals? What are changes in foraging and habitat patterns in different seasons, and years? What is the role of environmental covariates in distribution? One of our biggest questions is the possible change of foraging and habitat patterns in various seasons. Habitat modeling is needed to analyze relationships between sightings of dolphins, possible influences of varying riverine input and land use, and other environmental variables, such as temperature, salinity, distance to river mouths, and number/type of fishing vessels. Based on increased tourism and a growing coastal population, recommended research includes an assessment of threats, such as bycatch, plastic trash in the water, coastal development, pollution from groundwater runoff, and overfishing. Our goal is to continue to monitor this area with transect surveys every 5 years.

Although the abundance of dolphins in Trat is comparatively large, is this a sustainable population? The number of animals recently caught in nets is high compared to the abundance estimate, as evidenced by the bycatch we encountered during our years in the field. Between 2002 and 2013, 84 Irrawaddy dolphins have been found stranded in the eastern Gulf of Thailand (Teh et al., in press). This number, a probable underestimate, as not all bycaught animals are found, averages 10.5 dolphins per year. One method commonly used by marine mammal scientists to estimate if anthropogenic mortality is sustainable is the potential biological removal (PBR) (Wade, 1998). The equation,

$$
\mathrm{PBR}=\mathrm{N}_{\min } \frac{1}{2} \mathrm{R}_{\mathrm{MAX}} \mathrm{F}_{\mathrm{R}}
$$


is based on $N_{\min }$, the minimum population estimate, $1 / 2 R_{M A X}$, half of the maximum theoretical net productivity rate of the population group (the default for cetaceans is 0.04; Wade, 1998), and a recovery factor $F_{R}$. After Whitty (2014), we used 0.1, 0.5, and 1 . Using the average population estimate of $423, \mathrm{PBR}$ ranges from $0.85\left(\mathrm{~F}_{\mathrm{R}}=0.1\right)$, to $4.23\left(\mathrm{~F}_{\mathrm{R}}=0.5\right)$, to $8.46\left(\mathrm{~F}_{\mathrm{R}}=1\right)$. Wade (1998) concluded that an $F_{R}$ of 0.5 was least biased. An underestimated average of 10.5 bycaught dolphins per year is over twice the calculated PBR of 4.23. Such a large estimate of bycatch is unsustainable and could lead to the depletion of this population (Wade, 1998). These calculations could be used as the basis for goals in bycatch management. This issue is common, and reflects the important threat of marine mammal bycatch, identified as a serious regional problem during the recent Southeast Asian Marine Mammal Workshop (Hines et al., in press).

Another question is how education and environmental change are shifting the way that local fishers see and value their environment and the role of these top predators, and how their ideas of conservation and stewardship are changing. Values can change as the result of various factors, such as the perception of threats and scarcity, political and economic circumstances, community cohesion and pressures, generational memories, and exposure to media. Marine mammals have a living presence in the lives and imaginations of the communities where they are seen year after year. These associations between wildlife and humans are especially valuable, as it is only through local solutions, and with local cooperation that these animals can survive.

Our close collaboration with the Thai DMCR has enabled us to create a good working relationship with local scientists. This has enabled our work to be meaningfully applied in management planning. The long-term nature of this project has brought local and national attention to these marine mammals and the threats they face. Incidents of bycatch are featured in national media, and are communicated widely by local conservation organizations. DMCR scientists and Directors concerned are convinced that

\section{References}

Adulyanukosol, K. (1999). "Dugong, dolphin, and whale in Thai waters," in Proceedings of the 1st Korea-Thailand Joint Workshop on Comparison of Coastal Environment: Korea-Thailand, Seoul: Hoam Convention Center, Seoul National University.

Anderson, M., and Kinze, C. C. (1999). Annotated checklist and identification key to the whales, dolphins, and porpoises (Order Cetacea) of Thailand and adjacent waters. Nat. Hist. Bull. Siam Soc. 47, 27-62.

Beasley, I., Chooruk, S., and Piwpong, N. (2002). The status of the Irrawaddy dolphin, Orcaella brevirostris, in Songkhla Lake, Southern Thailand. Raffles Bull. Zool. (Suppl. 10), 75-83.

Bonhote, J. L. (1904). "Report on the mammals," in Fasciculi Malayenses; Anthropological and Zoological Results of an Expedition to Perak and the Siamese Malay States, 1901-1902. eds N. Annandale and H. C. Robinson (London: University Press of Liverpool), 200.

Buckland, S. T., Anderson, D. R., Burnham, K. P., Laake, J. L., Borchers, D. L., and Thomas, L. (2001). Introduction to Distance Sampling: Estimating Abundance of Biological Populations. Oxford, UK: Oxford University Press.

Buckland, S. T., Anderson, D. R., Burnham, K. P., Laake, J. L., Borchers, D. L., and Thomas, L. (2004). Advanced Distance Sampling. Oxford, UK: Oxford University Press. protected area zoning and increased protection from bycatch are needed, and have begun pressing for conservation planning. The Thai government has begun talks with Cambodia about a transboundary marine protected area that would include areas in both countries where coastal Irrawaddy dolphins are found.

\section{Author Contributions}

All authors have made substantial contributions to the conception and design of the work, and the acquisition and interpretation of these data. All authors were involved in drafting and revising this work, approving it for publication, and agree to be accountable for the accuracy and integrity of the work.

\section{Acknowledgments}

This research was conducted with the approval of the Institutional Animal Care and Use Committee of San Francisco State University. We would like to thank the National Research Council of Thailand for their cooperation and support through the national permitting process. Many scientists from the DMCR joined this project over the years and made it possible. We apologize that we do not have room to name you all! We acknowledge Ocean Park Conservation Foundation and the Indo-Pacific Cetacean Research and Conservation Fund for grants that enabled this project. Our work in Thailand was always supported by Kanjana Adulyanukosol, whose visits to our boat were so wonderful. We miss you. Many thanks to Tara Whitty, Satoko Kimura, Long Vu, Hoang Minh Duc, Cindy Peter and Isabelle Groc. Our volunteers were Michael Yuen, Jennifer Siu, Laura Morse, Jen McGowan and Andrea Dransfield. Our research vessel was driven beautifully each year by Captain Leigh and his son Aa. Pi Hom, our driver, is a community member dedicated to marine conservation who was instrumental to our work.
Chantrapornsyl, S., Adulyanukosol, K., and Kittiwathanawong, K. (1996). Records of cetaceans in Thailand. Phuket Mar. Biol. Cent. Res. Bull. 61, 39-63.

Chantrapornsyl, S., Adulyanukosol, K., and Kittiwattanawong, K. (1999). Stranded Cetaceans from Thailand. Int. Mar. Biol. Res. Inst. Rep. 9, 55-72.

CITES. (2004). Press Kit, Thirteenth Meeting of the Conference of the Parties. Convention on International Trade in Endangered Species of Wild Flora and Fauna. 2 - 4 October, 2004, Bangkok, Thailand. Available online at: www.cites.org/eng/cop/13/press_kit.pdf

Dawson, S., Wade, P., Slooten, E., and Barlow, J. (2008). Design and field methods for sighting surveys of cetaceans in coastal and riverine habitats. Mammal Rev. 38, 19-49. doi: 10.1111/j.1365-2907.2008.00119.x

Dick, D. M., and Hines, E. M. (2011). Development and implementation of distance sampling techniques to determine bottlenose dolphin (Tursiops truncatus) abundance at Turneffe Atoll, Belize. Mar. Mammal Sci. 27, 606-621. doi: 10.1111/j.1748-7692.2010.00435.x

Dolar, M. L. L., Perrin, W. F., Guadiano, J. P., Yaptinchay, A. A. S. P., and Tan, J. M. L. (2002). Preliminary report on a small estuarine population of Irrawaddy dolphins Orcaella brevirostris in the Philippines. Raffles Bull. Zool. 10, 155-160.

Hines, E., Adulyanukosol, K., Charuchinda, M., Somany, P., and Sam Ath, L. (2004). Conservation of dugongs (Dugong dugon) along the Eastern Gulf of Thailand in Thailand and Cambodia. Final Report to Ocean Park Conservation 
Foundation, Hong Kong, and Project Aware, Australia. Available online at: http://rtc.sfsu.edu/research/in_hines.html

Hines, E., Adulyanukosol, K., and Duffus, D. A. (2005). Dugong abundance along the Andaman coast of Thailand. Mar. Mammal Sci. 21,536-549. doi: 10.1111/j.1748-7692.2005.tb01247.x

Hines, E., Junchompoo, C., Ilangakoon, A., Ponnampalam, L., and JacksonRicketts, J. (2013). "Coastal Cetaceans in Trat Province, Eastern Thailand (2013)." Final Report to Ocean Park Conservation Foundation, Hong Kong and Indo-Pacific Cetacean Foundation, Australia. Available online at: http://rtc.sfsu.edu/research/in_hines.html

Hines, E., Junchompoo, C., Ilangakoon, A., Ponnampalam, L., and JacksonRicketts, J. (2014). Coastal Cetaceans in Trat Province, Eastern Thailand (20122014). Final Report to Indo-Pacific Cetacean Foundation, Australia. Available online at: http://rtc.sfsu.edu/research/in_hines.html

Hines, E., Ponnampalam, L. S., Hisne, F. I. J., Whitty, T. S., Jackson-Ricketts, J., Kuit, S. H., et al. (in press). Report of the 3rd Southeast Asian Marine Mammal Symposium (SEAMAM III). Langkawi Island: The Convention on Migratory Species of Wild Animals (CMS), United Nations Environment Program.

Junchompoo, C., Monanunsap, S., and Penpein, C. (2014). "Population and conservation status of Irrawaddy dolphins (Orcaella brevirostris) in Trat Bay, Trat Province, Thailand," in Proceedings of the Design Symposium on Conservation of Ecosystem (The $13^{\text {th }}$ SEASTAR2000 Workshop), Vol. 2, 32-38. Available online at: http://hdl.handle.net/2433/185132

Jutapruet, S. (2013). “Conservation: Songkhla lake, Thailand country report," in Report of the 3rd Southeast Asian Marine Mammal Symposium (SEAMAM III) (Langkawi Island: The Convention on Migratory Species of Wild Animals (CMS), United Nations Environment Program).

Kittiwattanawong, K., Chantrapornsyl, S., Ninwat, S., and Chooruk, S. (2007). "Review of the status and conservation of Irrawaddy dolphins Orcaella brevirostris in the Songkhla Lake of Thailand." in Status and Conservation of Freshwater Populations of Irrawaddy Dolphins, eds. B. D. Smith, R. G. Shore, and A. Lopez (Bronx, NY: Wildlife Conservation Society), 119.

Kreb, D. (2004). Abundance of freshwater Irrawaddy dolphins in the Mahakam in East Kalimantan, Indonesia, based on mark-recapture analysis of photoidentified individuals. J. Cetacean Res. Manage. 6, 269-277.

Kreb, D., and Lim, I. S. (2009). Balikpapan Bay Irrawaddy dolphin Project 2008. Final Technical Report. Conservation and diversity of cetaceans in and near Balikpapan Bay, East Kalimantan, Indonesia.

Kuit, S. H., Ponnampalam, L. S., Fairul Izmal, J. H., and Chong, V. C. (2014). "Cetacean research and a precautionary approach in developing dolphinwatching tourism in the coastal waters of the Matang mangroves," in Proceedings of the Matang Mangrove Forest Management Conference, (Ipoh), 27-39.

Minton, G., Peter, C., Zulkifli Poh, A. N., Ngeian, J., Braulik, G., Hammond, P. S., et al. (2013). Population estimates and distribution patterns of Irrawaddy dolphins (Orcaella brevirostris) and Indo-Pacific finless porpoise (Neophocaena phocaenoides) in the Kuching Bay, Sarawak. Raffles Bull. Zool. 61, 877-888.

Perrin, W. F., Reeves, R. R., Dolar, M. L. L., Jefferson, T. A., Marsh, H., Wang, J. Y., et al. (2005). Report of the Second Workshop on the Biology and Conservation of small cetaceans and dugongs of South-East Asia, CMS Technical Series. Dumaguete: Silliman University, 162.

Pilleri, G., and Gihr, M. (1974). "Contribution to the knowledge of the cetaceans of southwest and monsoon Asia (Persian Gulf, Indus delta, Malabar, Andaman
Sea and Gulf of Siam)," in Investigations on Cetacea, Vol. V, ed G. Pilleri (Berne: Institute of Brain Anatomy), 95-149.

Reeves, R. R., Jefferson, T. A., Karczmarski, L., Laidre, K., O'Corry-Crowe, G., Rojas-Bracho, L., et al. (2008). Orcaella brevirostris. The IUCN Red List of Threatened Species. Version 2014.3. Available online at: www.iucnredlist.org (February 02, 2015).

Reeves, R. R., Smith, B. D., Crespo, E. A., and Notobartolo di Sciara, G. (2003). (compilers). Dolphins, whales and porpoises: 2002-2010 Conservation Action Plan for the World's Cetaceans. Cambridge, UK: IUCN/SSC Cetacean Specialist Group IUCN.

Smith, B. D., Beasley, I., Buccat, M., Calderon, V., Evina, R., de Valle, J. L., et al. (2004). Status, ecology and conservation of Irrawaddy dolphins (Orcaella brevirostris) in Malampaya Sounds, Palawan, Philippines. J. Cetacean Res. Manage. 6, 41-52.

Smith, B. D., Beasley, I., and Kreb, D. (2003). Marked declines in populations of Irrawaddy dolphins. Oryx 37, 401-406. doi: 10.1017/S0030605303000723

Stacey, P. J. (1996). Natural History and Conservation of Irrawaddy Dolphins, Orcaella Brevirostris, with Special Reference to the Mekong River, P. D. R Lao. M.Sc Thesis, Department of Geography, University of Victoria.

Stacey, P. J., and Arnold, P. W. (1999). Orcaella brevirostris. Mammal. Species 616, $1-8$.

Stacey, P. J., and Leatherwood, S. (1997). The Irrawaddy Dolphin Orcaella brevirostris. a summary of current knowledge and recommendations for conservation action. Asian Mar. Biol. 14, 195-214.

Strindberg, S., and Buckland, S. T. (2004). Zigzag survey designs in line transect sampling. J. Agric. Biol. Environ. Stat. 9, 443-461. doi: $10.1198 / 108571104 X 15601$

Teh, L. C. L., Hines, E., Junchumpoo, C., and Lewison, R. (in press). Contexualizing the coupled socio-ecological conditions of marine megafauna bycatch. Ocean Coast. Manage.

Thomas, L., Buckland, S. T., Rexstad, E. A., Laake, J. L., Strindberg, S., Hedley, S. L., et al. (2010). Distance software: design and analysis of distance sampling surveys for estimating population size. J. Appl. Ecol. 47, 5-14. doi: 10.1111/j.1365-2664.2009.01737.x

Tongnunui, S., Wattanakornsiri, A., Pachana, K., Beamish, F. W. H., and Tongsukdee, S. (2011). Preliminary investigation of Irrawaddy dolphin (Orcaella brevirostris) in the Bangpakong Estuary, Inner Gulf of Thailand. Environ. Nat. Resour. J. 9, 48-57.

Wade, P. (1998). Calculating limits to the allowable human-caused mortality of cetaceans and pinnipeds. Mar. Mammal Sci. 14, 1-37.

Whitty, T. (2014). Conservation-scapes: An Interdisciplinary Approach to Assessing Cetacean by Catch in Small-scale Fisheries. Ph.D. dissertation, Scripps Institution of Oceanography.

Conflict of Interest Statement: The authors declare that the research was conducted in the absence of any commercial or financial relationships that could be construed as a potential conflict of interest.

Copyright (c) 2015 Hines, Strindberg, Junchumpoo, Ponnampalam, Ilangakoon, Jackson-Ricketts and Monanunsap. This is an open-access article distributed under the terms of the Creative Commons Attribution License (CC BY). The use, distribution or reproduction in other forums is permitted, provided the original author(s) or licensor are credited and that the original publication in this journal is cited, in accordance with accepted academic practice. No use, distribution or reproduction is permitted which does not comply with these terms. 